\title{
CLUB HOUSE REKREASI DAN SENI
}

\author{
Vicky Agusta Setiawan ${ }^{1)}$, Mieke Choandi²)
}

1)Program Studi S1 Arsitektur, Fakultas Teknik, Universitas Tarumanagara, vickyagusta17@gmail.com

2)Program Studi S1 Arsitektur, Fakultas Teknik, Universitas Tarumanagara, miekec@ft.untar.ac.id

\begin{abstract}
Abstrak
Jakarta, ibukota negara Indonesia merupakan kota yang jumlah penduduk mencapai 10.504.100 jiwa (Badan Pusat Statistik Jakarta, 2019) dengan kepadatan penduduk mencapai $16.704 \mathrm{jiwa} / \mathrm{km}^{2}$. Kepadatan penduduk Jakarta yang beragam pendidikan, sosial ekonomi dan budaya, membuat kota Jakarta hidup di dalam lingkungan dengan ciri khas dan aktivitas keseharian yang berbeda-beda pula. Setiap harinya penduduk Jakarta melakukan berbagai aktivitas, yang paling umum ialah di rumah dan di sekolah atau tempat kerja. Lama-kelamaan aktivitas menjadi sebuah rutinitas. Ketika aktivitas menjadi sebuah rutinitas, manusia pasti mengalami "kejenuhan". Salah satu solusi untuk menghilangkan "kejenuhan" ini diperlukan sebuah wadah di mana semua golongan masyarakat dapat beristirahat, berinteraksi, berekspresi dan menghibur diri dari rutinitas mereka hadapi, di mana seringkali wujudnya berupa Third Place. Kawasan Duri Kosambi terdiri dari tiga perumahan yang penghuninya jarang berinteraksi. Kawasan ini kemudian di survey sebagai bentuk metode perancangan konvensional untuk mengetahui kebutuhan warga. Salah satu Third Place yang dapat muncul di tengah-tengah ke tiga perumahan dengan karakteristik masyarakat yang beragam yaitu sebuah Club House yang lebih bertema 'rekreasi dan seni'. 'Rekreasi' untuk melepas "kejenuhan" dan 'Seni' berupa penambahan fasilitas kawasan untuk mengembangkan kreativitas dan keterampilan bagi warga masyarakat setempat. Dengan program utama berupa fasilitas lokakarya melukis, sanggar tari, dan studio musik. Club House Rekreasi dan Seni, diharapkan dapat menjadi titik simpul berkumpul dan beraktivitas bersama bagi setiap warga dari ke tiga perumahan berbeda. Dengan terbukanya akses bagi seluruh masyarakat, maka diharapkan terjadi interaksi antar sesama warga Duri Kosambi dari berbagai kalangan untuk menumbuhkan rasa persaudaraan, saling menghormati, saling berbagi ide dan informasi.
\end{abstract}

Kata kunci: club house; kejenuhan; perumahan; rekreasi dan seni; third place

\begin{abstract}
Jakarta City as the capital city of Indonesia is a city with a population of 10.504 .100 people (Jakarta Central Agency, 2019) and population density wih an average of 16.704 people $/ \mathrm{km}^{2}$. The population of Jakarta is crowded with various educational, economics, socio-cultural, and diverse backgrounds, making the people of Jakarta living in environment and daily activities that vary. Every day, the most common things they do are activities at home and at school or workplace. Gradually activities into routines, then people starting to experience "boredom". One solution to get rid of this "boredom" is required a place where everyone can rest, interact, express and entertain themselves, which usually in the form of Third Place. Duri Kosambi area consists of three housing whose inhabitants rarely interact with each other. The area was then surveyed as a form of conventional design methods to determine the needs of residents. Third Place that can be built between three different characteristics housing is a Club House with 'recreation and art' theme. 'Recreation' to get rid of "boredom" and 'Art' which is to develop the creativity and special skills of the residents. It's main programs are painting workshop, dance and music studio. This Club House Recreation and Art aims to create a new meeting point for the three different housing. With the opening of access point for the whole society, it also tries to create new interactions between fellow residents with diverse backgrounds to further develop a sense of brotherhood, mutual respect, sharing ideas and information.
\end{abstract}

Keywords: boredom; club house; housing; recreation and art, third place 


\section{PENDAHULUAN}

Sebagai ibukota negara, Jakarta dengan jumlah penduduk sebesar 10.504.100 juta jiwa (Badan Pusat Statistik Jakarta, 2019), menjadi salah satu kota dengan kepadatan penduduk yang sangat tinggi, yaitu dengan rata-rata mencapai $16.704 \mathrm{jiwa} / \mathrm{km} 2$. Jumlah penduduk Jakarta yang padat dengan faktor pendidikan, ekonomi, sosial budaya, serta latar belakang yang beragam, membuat masyarakat Jakarta hidup di dalam lingkungan dengan ciri khas dan aktivitas keseharian yang berbeda-beda pula. Perbedaan ini dapat dilihat langsung dan yang paling mencolok dapat dikategorikan menjadi dua, yaitu pertama, lingkungan di perumahan dan ke dua, kampung-kampung di tengah-tengah kota. Perbedaan ini tentunya disebabkan oleh faktor tingkat pendidikan dan ekonomi, serta kemajuan teknologi yang tidak dapat dicapai sama / setara oleh setiap individu.

Penduduk yang tinggal di lingkungan perumahan cenderung memiliki rutinitas dari rumah (first place) berangkat ke kantor / sekolah (second place) lalu pulang dan mencari hiburan di dalam rumah dengan bermain gadget atau pergi ke pusat perbelanjaan / café. Hal ini seringkali mendorong orang-orang kota memiliki sifat individualistis yang cukup tinggi dan kurang mau terbuka terhadap orang lain. Berbeda dengan penduduk yang tinggal di kampung, setelah pulang dari tempat kerja / sekolah, mereka cenderung akan mencari hiburan dengan berkumpul di depan rumah / posko dan berbagi cerita / informasi, serta melakukan aktivitas bersama-sama. Hal ini tentu menjaga sifat ramah-tamah dan gotong-royong yang memang kental di desa atau pedalaman.

Ke dua perbedaan mencolok ini kemudian dapat menimbulkan masalah kesenjangan sosial yang kemudian berkembang menjadi isu-isu lain, seperti kurangnya persatuan dan rasa percaya antar masyarakat, kriminalitas yang tinggi, kurangnya kepedulian serta belarasa antar golongan masyarakat maupun isu-isu sosial lainnya. Padahal di luar dari masalah yang berat itu, setiap masyarakat Jakarta menghadapi satu masalah umum / dasar yang tanpa pandang bulu, siapapun dari golongan manapun pasti mengalami apa yang disebut dengan "kejenuhan". Setiap harinya penduduk Jakarta melakukan berbagai aktivitas dan yang paling umum ialah di rumah dan di sekolah atau tempat kerja. Lama-kelamaan aktivitas menjadi sebuah rutinitas dan ketika aktivitas menjadi sebuah rutinitas, manusia pasti akan menghadapi titik jenuh dan membutuhkan wadah untuk istirahat sejenak dari rutinitas dan menghilangkan kejenuhan tersebut. Wadah yang biasa disebut Third Place merupakan jawaban untuk menghilangkan kejenuhan dari rutinitas sehari-hari. Third Place merupakan sebuah tempat yang dapat bebas dikunjungi oleh semua lapisan masyarakat untuk berinteraksi, bersosialisasi, menyalurkan hobi, dan melakukan berbagai kegiatan lainnya. Bentuk tempat ini dapat menjadi berbagai macam, namun biasanya bersifat hiburan, keramahan, maupun komersil. Third Place merupakan tempat di luar rumah dan sekolah atau tempat kerja yang menjadi tempat berekreasi, keluar dari rutinitas bagi siapapun.

\section{KAJIAN LITERATUR}

\section{Open Architecture}

Setiap manusia mengenal istilah "first place" yang berupa tempat tinggal (home) dan "second place" yang berupa tempat aktivitas utama seperti bersekolah / bekerja (work), yang keduanya tak bisa lepas dari kehidupan sehari-hari manusia. Open Architecture merupakan sistem yang terbuka dan mampu beradaptasi, di luar "first place" dan "second place" yang berfungsi sebagai ruang antara atau biasa dibilang "the third place" bagi masyarakat kota. Memasuki jaman modern ini, kota-kota besar memiliki permasalahan yang sama yaitu ciri masyarakat yang individualistis dan sangat sensitif terhadap personal space-nya. Kondisi ini terkadang menyebabkan gesekkan antar individu dan menjadi konflik serta pertimbangan penting saat menegaskan perbedaan publik privat. Namun, dalam Open Architecture sebagai the third place 
konflik tersebut menjadi berpotensi untuk dikembangkan dan dapat membantu masyarakat kota agar bersifat humanis, terbuka, dinamis dan produktif.

\section{The Third Place}

Peradaban yang hebat, seperti pada kota-kota besar, memiliki fasilitas umum yang bersifat publik dengan pemakaiannya bersama, sehingga kota menjadi "tempat" bersama yang dibagi antar masyarakat dikenal dengan konsep "sharing cities". Di antara fasilitas umum yang terus berkembang berdasarkan kebutuhan kota merupakan tempat berkumpul informal. Tempattempat berkumpul ini menjadi bagian dari lansekap kota yang dipenuhi dengan kehidupan sehari-hari penduduk kota dan kemudian menjadi citra sebuah kota. Seperti kota Paris yang terkenal dengan café - café pinggir jalannya; kota Roma yang khas dengan forum-forumnya; London yang khas dengan tempat minumnya dan Florence dengan plaza-plazanya atau rumahrumah teh di Jepang yang menggambarkan cara hidup masyarakat mereka. Semua contoh ini mewakili lembaga mediasi antara individu dan masyarakat sosial.

Tempat berkumpul publik tersebut disebut sebagai Third Place dan memiliki ciri-ciri berikut (The Great Good Place, 1997); 1) Bersifat netral, 2) Bersifat setara, 3) Dialog adalah aktivitas utama, 4) Mudah diakses, 5) Memiliki pengunjung tetap, 6) Secara fisik bersifat sederhana, 7) Bernuansa ceria. Duncan McLaren dan Julian Agyeman dalam buku Sharing Cities (2015) menyatakan, ketika bicara tentang "sharing cities", terdapat 2 makna dari "sharing" (sebagai kata kerja dan sifat "berbagi"). Dalam buku Sharing Cities dikupas juga kasus untuk memahami "kota sebagai ruang bersama" dan digunakan oleh siapapun secara adil. Efek dari kepadatan penduduk dan ruang publik bergabung dengan berkembangnya teknologi baru akhirnya menghadirkan permintaan dan pasokan dari sumber daya dan fasilitas bersama (peluang untuk berbagi pun muncul dan meningkat). Hal ini memiliki dampat positif, namun juga dapat memunculkan dampak negatif. Untuk mencegah hal-hal negatif tersebut, "sharing the whole city" disarankan menjadi panduan utama kota di ke depannya. Mengangkat "paradigma berbagi" menawarkan peluang untuk kota menjadi sustainable.

\section{Generasi Milenial}

Orang-orang yang lahir dari tahun 1980 hingga 2000 sebagai penduduk milenial memiliki minat keinginan yang spesifik dalam menjalankan kehidupan sehari-harinya. Kaum milenial memiliki pandangan yang baru dan cukup berbeda, sehingga timbul juga gaya hidup baru yang cukup berbeda dibandingkan dengan generasi sebelumnya. Hal ini dikarenakan adanya perkembangan teknologi dan faktor-faktor yang timbul pada perubahan jaman lainnya. Pada umumnya, banyak hal yang bisa mencirikan milenial (Millennials: A Portrait of Generation Next, 2010): terlahir selaras dengan perkembangan teknologi, lebih memilih jalur instan, memiliki jiwa sosial yang tinggi, memiliki toleransi yang lebih tinggi, dapat melakukan berbagai aktivitas secara bersamaan dan lebih memilih kehidupan yang bersifat bersama.

Milenial, sebagaimana yang telah disurvei oleh IDN Times, merupakan golongan generasi yang paham tentang perkembangan teknologi. Teknologi ini mencakup beragam aspek yang hadir dalam kehidupan sehari-hari, sehingga seringkali terlihat dalam hidup mereka, penduduk milenial memanfaatkan dan menerapkan produk-produk teknologi. Menurut riset CSIS 2017 dan IDN Times 2019, penduduk milenial telah beralih perangkat dalam mengakses konten informasi, baik untuk keperluan referensi pengetahuan maupun untuk mengisi waktu luang . Hal paling signifikan yang terlihat dari kaum milenial dibandingkan generasi sebelumnya ialah kecenderungan mereka yang menghabiskan banyak waktu untuk mengakses konten yang bersifat digital, berbasis web atau cloud computing. Dengan menggunakan metode ini, perpindahan informasi lebih mudah dan waktu untuk mendistribusikan informasi menjadi lebih singkat. Kecenderungan ini telah menggeser buku yang merupakan sumber refensi 
teraktual, meskipun konten digital tidak seluruhnya gratis, sehingga tidak dapat diakses oleh seluruh masyarakat secara bebas. Menurut IDN Times, tujuan akses internet untuk kaum milenial masih didominasi dengan motivasi konektivitas antar sesama (chatting/ messaging $81,3 \%$ dan jejaring sosial 74,4\%) dan mencari berbagai informasi di internet (browsing $77,4 \%$ ). Dapat disimpulkan, kaum milenial lebih memprioritaskan realita kehidupan keseharian yang menjunjung tinggi konektivitas antar sesama. Sifat dasar kaum milenial yang berupa rasa keingintahuan yang tinggi menjadi pendorong dalam proses pembelajaran, baik secara otodidak maupun jika diajari. Konten digital seringkali digunakan sebagai sarana untuk belajar lebih lanjut tentang minat masing-masing individu, yang tentunya bertujuan untuk pengembangan diri demi menghasilkan karya-karya baru otentik demi mendapatkan pengakuan, baik dari diri sendiri atau lingkungan sekitar.

\section{METODE}

Menggunakan metode perancangan konvensional, didalamnya terdapat tiga tahapan yaitu input, analisa dan output. Input berupa data-data yang didapat dari studi literatur, survey tapak dan kawasan sekitar, serta studi kasus yang ada. Setelah berbagai data yang diperlukan terkumpul, maka tahap selanjutnya adalah menganalisis berbagai data tersebut hingga akhirnya mendapatkan sintesis dan output yang akhirnya menjadi acuan dalam merancang proyek.

\section{METODE PERANCANGAN KONVENSIONAL}

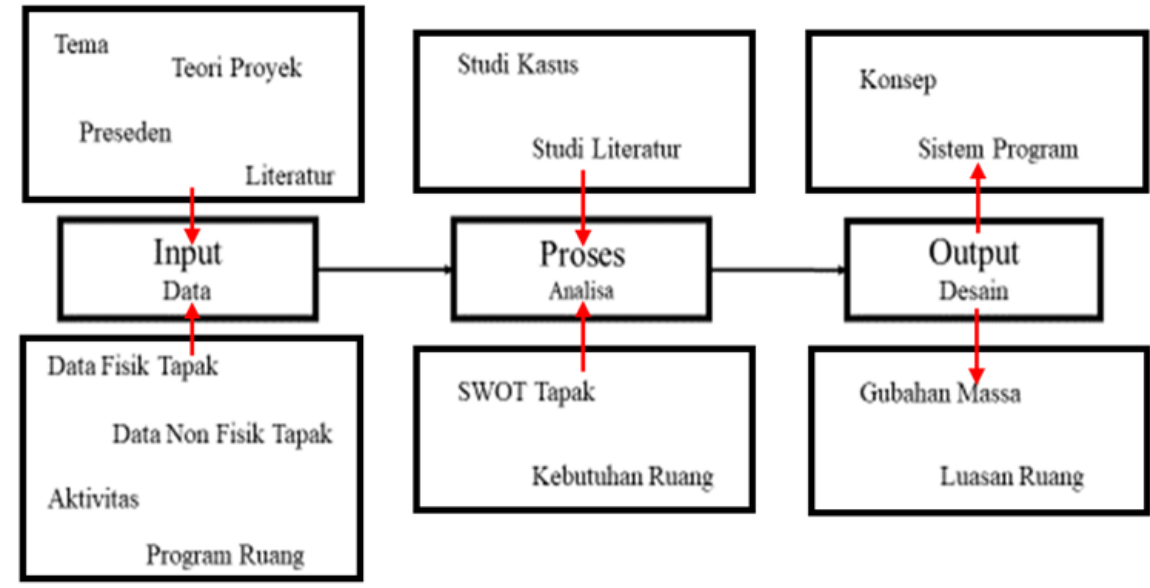

Gambar 1. Metode Perancangan Konvensional Sumber: Pribadi, 2020

\section{DISKUSI DAN HASIL}

Club House Rekreasi dan Seni terletak di Jakarta Barat berada dalam Kawasan Duri Kosambi, menduduki lahan kosong dan beberapa bangunan eksisting dengan fungsi rumah tinggal yang terletak di sudut salah satu komplek perumahan Taman Semanan Indah di depan JI. Dharma Pratama dan Jl. Dharma Kusuma, bersebelahan dengan komplek perumahan Kosambi Baru maupun berseberangan dengan kawasan kampung Haji Mali dengan pemisah berupa Kali Semanan. Kondisi eksisting tapak perancangan merupakan lahan kosong dan beberapa bangunan rumah tinggal dengan ketinggian bangunan $2-3$ lantai. Tapak bersebelahan dengan Kali Semanan dan berada di sudut komplek dengan akses tertutup 1 gerbang, sehingga jarang dilewati oleh kendaraan dan aman untuk penghuni komplek maupun pejalan kaki.

\section{Pemilihan Lokasi}

Lokasi berada di Kawasan Duri Kosambi, tepatnya berada di dalam Perumahan Taman Semanan Indah yang bersebelahan dengan komplek perumahan Kosambi Baru maupun berseberangan dengan kawasan kampung Haji Mali dengan pemisah berupa Kali Semanan. Kondisi eksisting ketiga area perumahan ini kurang terhubung dan terintegrasi satu sama lain 
dikarenakan masalah keamanan serta perbedaan status sosial ekonomi. Namun, lokasi tapak juga bisa dibilang strategis karena menurut RDTR ke depannya akan dibuat jalan yang lebar di depan tapak, sehigga tapak yang berdekatan dengan ke tiga perumahan dapat menjadi sebuah titik kumpul, penghubung, pemersatu yang aman dan menjangkau kebutuhan masyarakat sekitar yang eksistingnya belum ada.
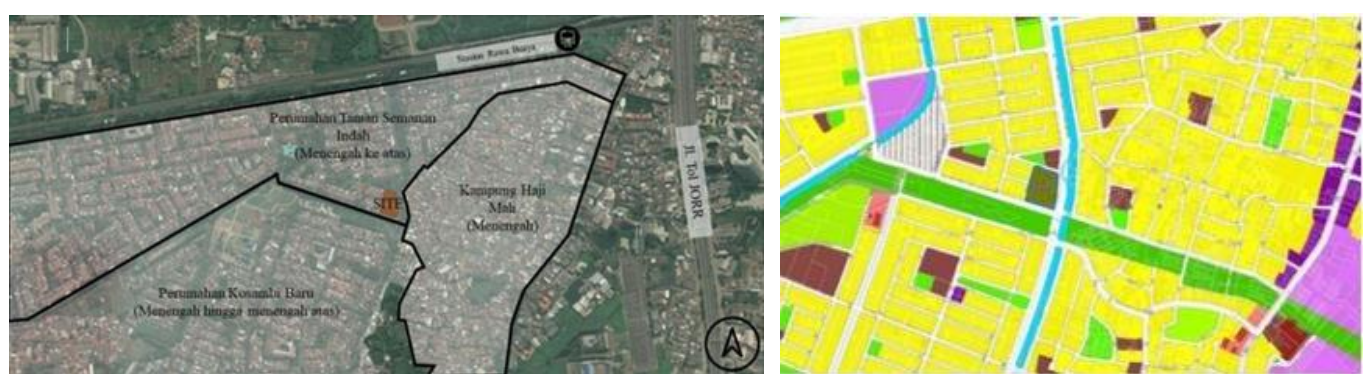

Gambar 2. Lokasi Tapak (Jl. Dharma Kusuma, Duri Kosambi, Jakarta Barat) Sumber: Google Earth dan Jakarta Satu, 2020

Perbedaan kondisi kehidupan yang terbilang menengah ke atas pada Perumahan Taman Semanan Indah dengan kondisi menengah sampai menengah ke atas pada Perumahan Kosambi Baru serta kondisi menengah pada kawasan kampung Haji Mali merupakan suatu tantangan tersendiri yang perlu diperhatikan untuk menyediakan sarana bersama yang bersifat netral. Sesuai peraturan zonasi, tapak perancangan memiliki peraturan pembangunan sebagai berikut; 1) KDB : 60\% [2.460 m2], 2) KLB : 1,2 [4.920 m2], 3) KB : 2, 4) KDH : $20 \%$ [820 m2], 5) KTB : 0 . Sesuai dengan peraturan zonasi, tapak perancangan berada di lahan yang diperuntukkan bagi zona perumahan KDB sedang-tinggi (subzona R.4). Mengacu kepada tabel peraturan perubahan zonasi, zona tersebut diijinkan untuk dialihfungsikan sebagai pendidikan khusus, tempat bermain lingkungan, taman rekreasi, lapangan olah raga, mini market, serta game center. Dengan program utama proyek berupa sebuah fasilitas yang dapat menjawab dan menunjang kebutuhan semua lapisan masyarakat, maka dimungkinkan secara administratif untuk dapat memanfaarkan tapak perancangan sebagai sebuah wadah untuk menjadi sarana rekreasi bagi masyarakat sekitar.

\section{Fasilitas Kawasan}

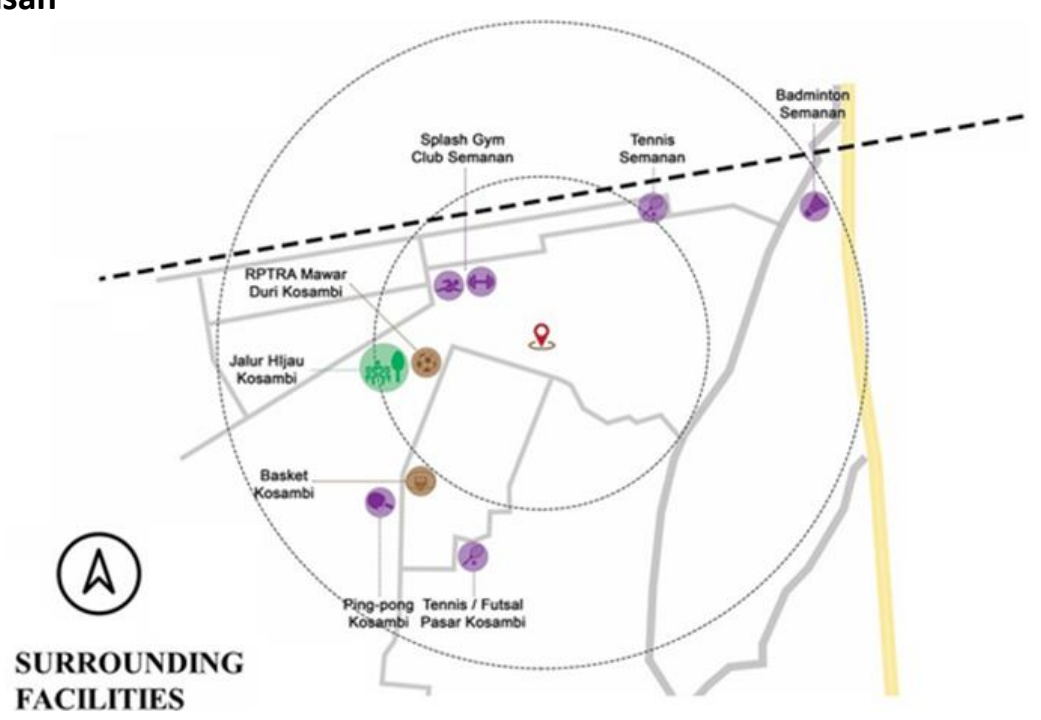

Gambar 3. Peta Fasilitas Kawasan

Sumber : Penulis, 2020 
Kawasan Duri Kosambi mayoritas berisi area perumahan, sehingga sudah sewajarnya terdapat berbagai fasilitas yang muncul dan tersebar di tengah-tengah area perumahan pada kawasan. Setelah melakukan survey lokasi dan pengamatan berkala, berikut mapping lokasi dari berbagai fasilitas eksisting yang menunjang kebutuhan masyarakat kawasan.

\section{Keseharian Penduduk Kawasan}

Dari hasil survey lokasi serta wawancara juga didapatkan bahwa aktivitas yang diminati oleh masyarakat kawasan ini ialah cukup beragam yang mayoritas berdasarkan kelompok usia. Perilaku ini pun dapat diangkat menjadi program utama yang dapat menarik masyarakat kawasan ke dalam proyek.

Tabel 1 Aktivitas dan Minat Warga Kawasan Duri Kosambi

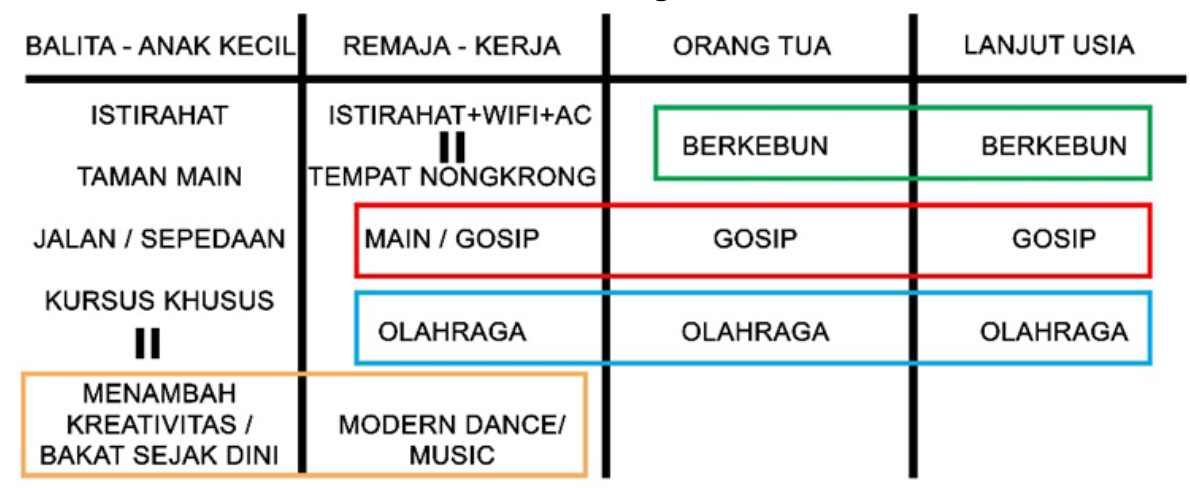

Sumber : Penulis, 2020

Menurut data demografi dari BPS tahun 2016, kelompok usia warga Kecamatan Cengkareng menunjukkan bahwa jumlah usia balita dan usia produktif cukup tinggi. Berdasarkan data ini, maka progam yang ada di dalam proyek sekiranya harus disesuaikan dengan rasio jumlah penduduk berdasarkan kelompok umur pada kawasan.

Tabel 2. Jumlah Penduduk Kecamatan Cengkareng menurut Kelompok Umur dan Jenis Kelamin

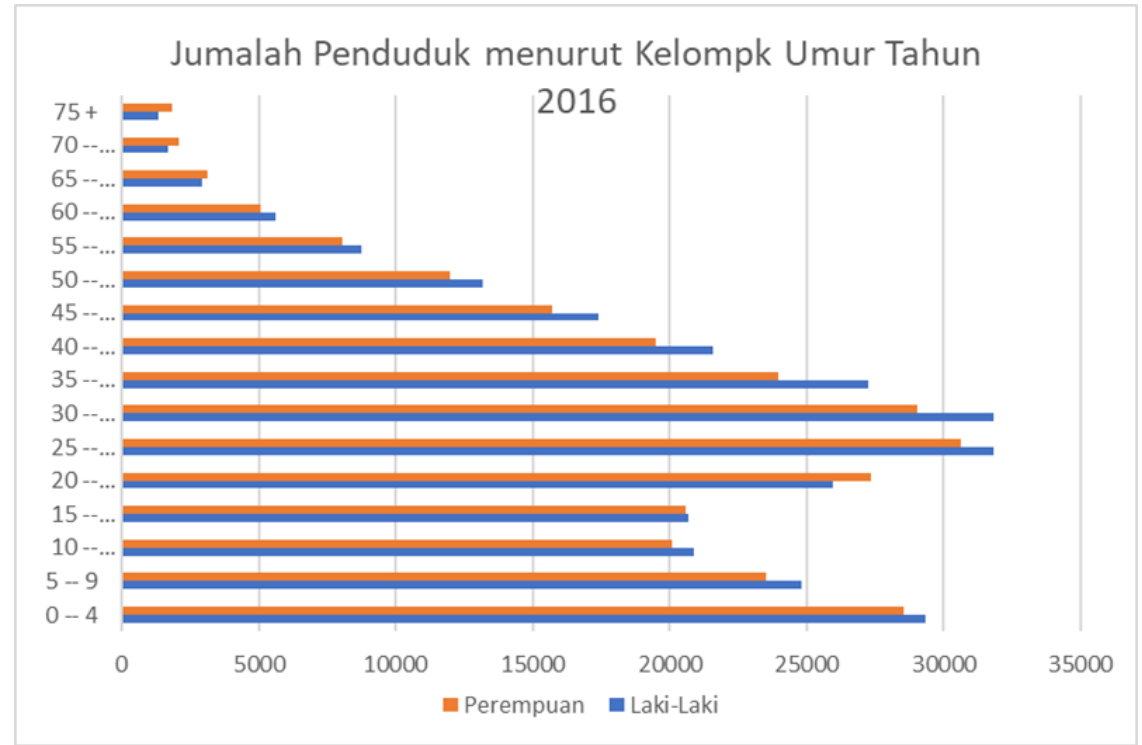

Sumber : BPS Kota Administrasi Jakarta Barat, 2020 


\section{Analisis dan Program}

Berikut penjabaran dari program-program yang diusulkan:

a. Workshop melukis \& grafir kayu (lukis bakar), sanggar tari serta studio musik (Hospitality), menjadi program yang muncul setelah dilakukan survey dan observasi dari kebutuhan fasilitas yang dibutuhkan masyarakat kawasan.

b. Board game \& café (Commercial), usulan program yang muncul karena biasanya aktivitas warga yang bercengkerama di café, berupa makan atau bermain. Dengan program ini, pengunjung dapat tetap berkumpul asik baik dengan listrik atau tanpa listrik (banjir dan mati lampu). Permainan board game juga banyak yang dapat dimainkan dari usia anak-anak hingga orang tua.

c. Minimarket sejenis Alfa $\mathrm{X}$ (Commercial), menjadi program yang muncul karena sifat masyarakat yang konsumtif khususnya terhadap makanan, namun jarak mini market sekitar cukup jauh, serta dibutuhkannya wadah untuk menampung aktivitas berupa bercengkerama yang diminati warga.

d. Ruang publik (Entertainment), salah satu program yang dapat diakses penuh selama 24 jam dan bertujuan agar terjadi interaksi antar sesama pengunjung. Terdiri dari area santai (untuk duduk-duduk dan beristirahat), area olahraga (tersedia fasilitas untuk olahraga) serta area bermain anak.

\section{Konsep Perancangan}

Konsep perancangan berupa lansekap yang disisipkan ke tengah-tengah bangunan arsitektur serta sirkulasi dan tata ruang yang interaktif dengan tujuan untuk memberikan "kesegaran" yang menghilangkan kejenuhan di manapun pengunjung berada di dalam proyek. Proses pembentukkan massa disesuaikan dengan analisis dan sintesis tapak kawasan lalu pembentukan ruang disesuaikan dengan fungsi bangunan.

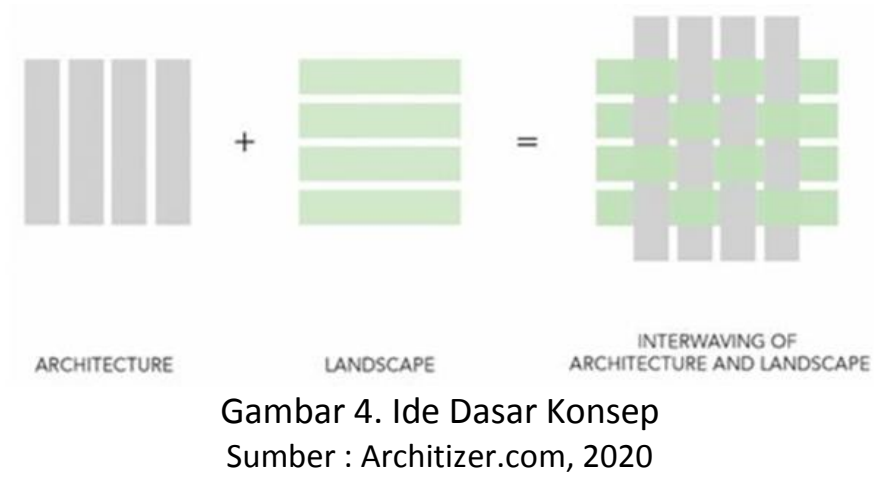

\section{Skema Perancangan Gubahan Massa}

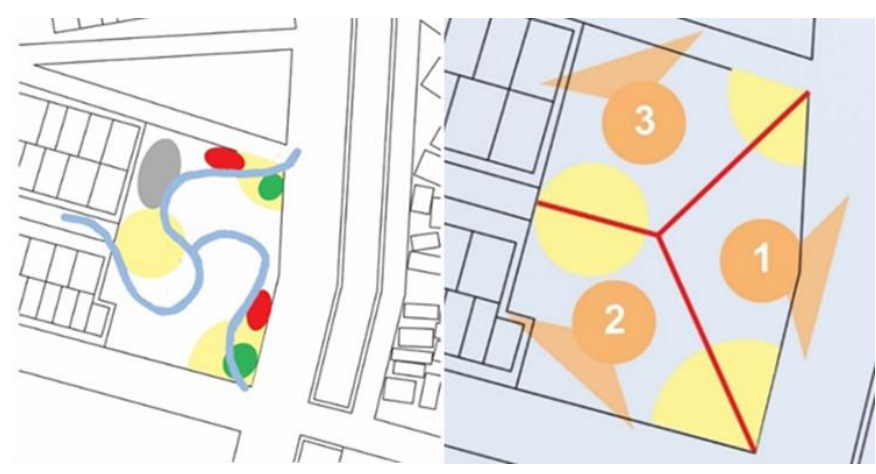

Gambar 5. Sintesis dan Pembagian Tiga Zona Utama

Sumber : Penulis, 2020 
Mula-mula setelah melakukan analisis, didapatkan 3 buah meeting point utama pada tapak. Meeting point ini kemudian dihu-bungkan dengan menarik garis lurus menuju ke pusat tapak, sehingga tapak terbagi menjadi 3 area. Setiap dari area ini menghadap ke arah 3 perumahan berbeda dengan karakteristik yang berbeda. Setiap area ini akan dirancang sesuai dengan karakteristik dari 3 perumahan tersebut;

a. Kawasan Haji Mali, skyline bangunan mayoritas rendah dan status ekonomi paling rendah di antara ke tiga perumahan, sehingga gubahan massa pada daerah ini dibuat rendah hanya 1 lantai saja.

b. Perumahan Kosambi, skyline bangunan mayoritas 2 lantai dan status ekonomi menengah hingga menengah atas, sehingga gubahan massa pada daerah ini dibuat seperti bercampur, bertumpuk ataupun berundak.

c. Perumahan Taman Semanan, skyline bangunan $2-3$ lantai dan status economi paling tinggi di antara ke tiga perumahan, sehingga gubahan massa pada daerah ini akan dibuat massif dan padat.

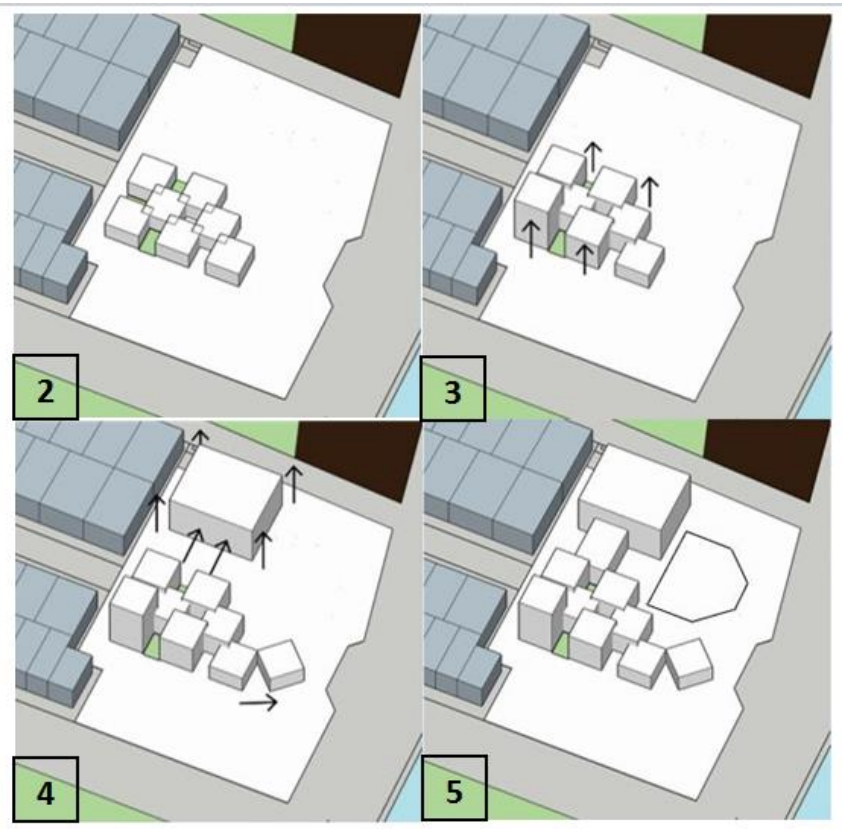

Gambar 6 Proses Gubahan Massa

Sumber : Penulis, 2020

Ke dua, proses gubahan massa dimulai dari area dua (menghadap Perumahan Kosambi, lihat acuan gambar 5) dikarenakan lebih netral dengan kondisi di tengah-tengah antara Semanan dan Haji Mali. Gubahan massa dibuat bercampur dan bertumpuk satu sama lainnya dengan modul 8x8m dan diterapkan konsep berupa lansekap yang disisipkan ke tengah-tengah bangunan arsitektur. Ke tiga, massa pada area dua ini kemudian dinaikkan ke atas dan dibuat berundak-undak dari ter-pendek hingga tertinggi (terpendek dimulai dari massa yang paling dekat dengan area 1) mengikuti karakter dari area 2 dan Perumahan Kosambi yang skyline bangunan dan status ekonomi menengah hingga menengah atas. Ke empat, menambahkan massa pada area satu dan tiga mengikuti karakter dari area masing-masing. Pada area satu dibuat rendah hanya satu lantai saja dan arahnya mengikuti sirkulasi yang telah diperoleh dari tahap analisis, sedangkan massa pada area tiga dibuat masif dan padat.

Ke lima, dilakukan penambahan penghubung antar massa. Penghubung antara massa pada area dua dan tiga menjadi bangunan dengan fungsi penunjang. Penghubung antara massa bangunan pada area satu hingga area tiga berupa area outdoor plaza utama. Ke enam, sirkulasi diubah disesuaikan dengan sifat penduduk yang "kepo" atau suka penasaran, sehingga 
terbentuklah bentuk gubahan yang akan mengarahkan pengunjung untuk mengeksplorasi Third Place. Sirkulasi menjadi lambang peleburan atau penyatuan sebagaimana tujuan dari Third Place ini, menciptakan wadah untuk berkumpul dan berinteraksinya warga dari tiga perumahan berbeda dengan fasilitas untuk menjawab dan menunjang kebutuhan mereka.

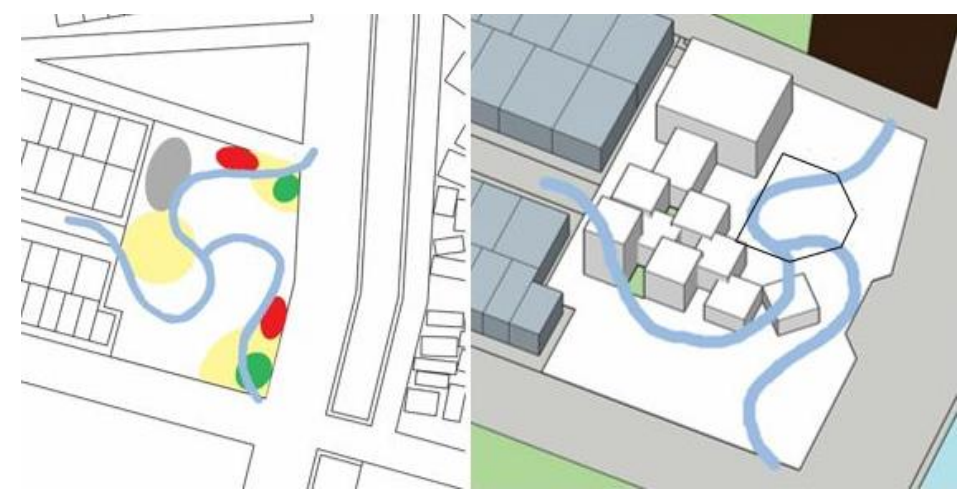

Gambar 7 Sirkulasi Sebagai Lambang Peleburan atau Penyatuan

Sumber : Penulis, 2020

\section{KESIMPULAN DAN SARAN}

Untuk menjawab permasalahan masyrakat kota akan sebuah wadah yang dapat menghilangkan kejenuhan dari rutinitas sehari-hari serta untuk menyediakan fasilitas yang memadai untuk masyarakat sekitar, maka diperlukan suatu Third Place yang fungsi dan program-programnya dapat mencerminkan kebutuhan atau karakteristik kawasan serta menjawab kebutuhan masyarakat sekitar kawasan. Setelah melakukan pengumpulan data dan melakukan analisa, maka didapatkan tapak berada di Perumahan Taman Semanan Indah, Duri Kosambi tepatnya lahan di sudut salah satu komplek Perumahan Taman Semanan Indah, bersebelahan dengan komplek Perumahan Kosambi Baru maupun bersebrerangan dengan kawasan kampung Haji Mali yang dibatasi oleh Kali Semanan.

Berdasarkan hasil dari survey dan observasi langsung, maka diajukan untuk membuat sebuah Club House sebagai fasilitas untuk menjawab dan menunjang kebutuhan warga perumahan sekitar dengan program-program yang berupa workshop lukis, sanggar tari, studio musik, board game café, mini market serta ruang publik. Proses pembentukan gubahan massa mulamula diawali dengan melakukan analisis dan sintesis tapak perancangan untuk mendapatkan zoning dan orientasi bangunan. Konsep bangunan yang berupa lansekap yang disisipkan ke tengah-tengah bangunan arsitektur kemudian diterapkan ke dalam gubahan. Terakhir, gubahan massa kemudian disesuaikan dengan karakter dari area perumahan yang ada di sekitar tapak serta penambahan konektor antar massa bangunan. Dirancang dengan konsep Open Architecture, proyek Club House ini memiliki peran penting dalam menciptakan peluang terjadinya interaksi antar sesama penduduk dari berbagai kalangan untuk menumbuhkan rasa persaudaraan, saling menghormati, saling berbagi ide dan informasi.

\section{REFERENSI}

Akcan, E. (1984). Open Architecture: Migration, Citizenship and the Urban Renewal of BerlinKreuzberg. Basel

Archdaily. PIXELAND / 100architects. Diakses 15 Februari 2020, dari https://www.archdaily.com/915563/pixeland-100architects

Architizer.A Thousand Yards Botanical Pavilion. Diakses 15 Februari 2020, dari https://architizer.com/projects/a-thousand-yards-pavilion/

Architizer. Alun Alun Cicendo 'Steel Plaza'. Diakses 15 Februari 2020, dari https://architizer.com/projects/alun-alun-cicendo-steel-plaza/ 
Badan Pusat Statistik. Jumlah Penduduk DKI Jakarta. Diakses 12 Februari 2020, dari https://www.jakarta.bps.go.id/

Badan Pusat Statistik. Jumlah Penduduk Kecamatan Cengkareng. Diakses 12 Februari 2020, dari https://www.jakarta.bps.go.id/

Dezeen. Penda designs modular wooden "village" for Beijing Horticultural Expo. Diakses 15 Februari 2020, dari https://www.dezeen.com/2017/01/19/penda-thousand-yards-pavilionmodular-wooden-village-beijing-horticultural-expo/

McLaren, D. \& Agyeman, J. (2015). Sharing Cities: A Case for Truly Smart and Sustainable Cities. London: MIT Press

Oldenburg, R. (1999). The Great Good Place. Washington DC: Da Capo Press

Pew Research Center. (2010). Millennials: A Portrait of Generation Next. Washington DC: Pew Research Center

Utomo, W. P. (2019). Indonesia Millennial Report 2019. Jakarta: IDN Research Institute 